\title{
Particulate organic matter in Antarctic summer sea ice: concentration and stable isotopic composition
}

\author{
H. Kennedy ${ }^{1, *}$, D. N. Thomas ${ }^{1}$, G. Kattner ${ }^{2}$, C. Haas $^{2}$, G. S. Dieckmann ${ }^{2}$ \\ ${ }^{1}$ School of Ocean Sciences, University of Wales, Bangor, Menai Bridge, Anglesey LL59 5EY, Wales, UK \\ ${ }^{2}$ Alfred Wegener Institute for Polar and Marine Research, Am Handelshafen 12, 27515 Bremerhaven, Germany
}

\begin{abstract}
The chemical and isotopic data from sea ice collected over a wide area of the Weddell Sea, Antarctica, during the austral summer/early autumn illustrate the range of environmental conditions under which ice algae grow. A range of ice types and features were sampled including intact and layered ice floes and surface ponds. Sea ice communities were found in all these environments but the highest biomasses were found either at the base of ice floes, or in the interior of layered floes with quasi-continuous horizontal gaps at or shortly below the water level. In the layered floes, particulate organic carbon (POC) measured in the ice layer immediately overlying the gap water (280 to $6014 \mu \mathrm{mol} \mathrm{dm}{ }^{-3}$ ) was in excess of what would be predicted if algal growth had occurred in a closed environment. The chemical composition of the gap water was strongly affected by biological activity in the overlying ice, which acts as a physical support for the algae retained within its matrix. The lowest range of POC (27 to $739 \mu \mathrm{mol} \mathrm{dm}{ }^{-3}$ ) conformed to predictions of algal growth in a closed system and samples were collected from the interior of ice floes where there was essentially no potential for nutrient exchange. The surface ponds displayed nitrate $\left(\mathrm{NO}_{3}{ }^{-}\right)$exhaustion and total dissolved inorganic carbon $\left(\mathrm{CCO}_{2}\right)$ reductions consistent with nutrient limited algal growth. The stable carbon isotopic composition of the particulate organic matter (POM) across all habitat types sampled $\left(\delta^{13} \mathrm{C}_{\mathrm{POC}}\right.$ -10.0 to $-27.3 \%$ ) displayed a wide range but was much less variable than the range of POC concentrations might have implied. The assumption that the highest biomass of algae in sea ice will result in the most positive $\delta^{13} \mathrm{C}_{\mathrm{POC}}$ values cannot be generally applied. The isotopic composition of dissolved inorganic carbon $\left(\delta^{13} \mathrm{C}_{\Sigma \mathrm{CO}_{2}}\right)$ in gap waters and surface ponds varied from 0.15 to $3.0 \%$ and was shown to be commensurate with the changes predicted from $\mathrm{NO}_{3}{ }^{-}$deficits caused by algal growth.
\end{abstract}

KEY WORDS: POM · Antarctic sea ice $\cdot$ Ice macroalgae $\cdot$ Carbon isotopic composition Resale or republication not permitted without written consent of the publisher

\section{INTRODUCTION}

Microbial assemblages in Antarctic pack ice are generally distributed throughout the floes as bottom, surface or internal assemblages (Palmisano \& Garrison 1993, Ackley \& Sullivan 1994). Chlorophyll (chl a) concentrations as high as $2000 \mathrm{\mu g} \mathrm{dm}^{-3}$ have been reported (Palmisano \& Garrison 1993, Nicol \& Allison 1997), demonstrating that algal growth can be a common feature of sea ice habitats. Algal growth in the interstitial brine of sea ice causes changes in its chem-

*E-mail: h.a.kennedy@bangor.ac.uk ical composition. Comparison of summer and winter conditions in the interstitial brine of Antarctic pack ice illustrates these changes in response to the increased algal growth during the summer with little exchange of nutrients with the surrounding seawater (Gleitz et al. 1995). Large reductions in total dissolved inorganic carbon $\left(\mathrm{CCO}_{2}\right)$, nutrients and dissolved carbon dioxide $\left(\mathrm{CO}_{2}(\mathrm{aq})\right)$ as well as increases in dissolved oxygen $\left(\mathrm{O}_{2}\right)$ and $\mathrm{pH}$ have been documented (Gleitz et al. 1995). Similar chemical changes have also been observed in other sea ice habitats such as meltwater pools (Gleitz et al. 1996b) and platelet ice layers (Günther et al. 1999, Thomas et al. 2001). Less extreme, but still observable trends may occur in water underlying sea ice (Gibson 
\& Trull 1999). During an annual study in Prydz Bay, Antarctica, a reduction in fugacity of $\mathrm{CO}_{2}\left(\mathrm{fCO}_{2}\right)$ was measured in concert with $\mathrm{\Sigma CO}_{2}$ consumption, caused by sea ice algae living within and on the bottom surface of the ice (Gibson \& Trull 1999). A reduction in $\left[\mathrm{CO}_{2}(\mathrm{aq})\right]$ may have physiological consequences for sea ice algae. However, model calculations have shown that diffusive uptake of $\mathrm{CO}_{2}(\mathrm{aq})$ is sufficient to satisfy the carbon demand of these algae when grown under conditions of low $\left[\mathrm{CO}_{2}(\mathrm{aq})\right]<0.5 \mu \mathrm{M}$ (Gleitz et al. 1996a).

The carbon isotopic composition of sea ice algae $\left(\delta^{13} \mathrm{C}_{\mathrm{POC}}\right)$ reflects changes in the chemical composition of their environment. Marine phytoplankton fractionate carbon isotopes during photosynthesis and the degree of fractionation $\left(\varepsilon_{\mathrm{p}}\right)$, calculated as the isotopic difference between $\mathrm{CO}_{2}$ (aq) (i.e. $\delta^{13} \mathrm{C}_{\mathrm{CO}_{2} \text { (aq) }}$ ) and POC (i.e. $\delta^{13} \mathrm{C}_{\mathrm{POC}}$ ) is affected by the relative rates of diffusional supply of $\mathrm{CO}_{2}(\mathrm{aq})$ to the cell and the relative rate of fixation of $\mathrm{CO}_{2}$ by the cell (Francois et al. 1993, Laws et al. 1997). Field observations show that $\varepsilon_{\mathrm{p}}$ and $1 /\left[\mathrm{CO}_{2}(\mathrm{aq})\right]$ exhibit a negative linear trend (Laws et al. 1995, Rau et al. 1997). The slope of the trend is directly influenced by growth rate $(\mu)$. When growth rate/cellular demand is constant a reduction of $\left[\mathrm{CO}_{2}(\mathrm{aq})\right]$ results in smaller $\varepsilon_{\mathrm{p}}$ values (Francois et al. 1993, Rau et al. 1997). Alternatively, at a constant diffusional flux of

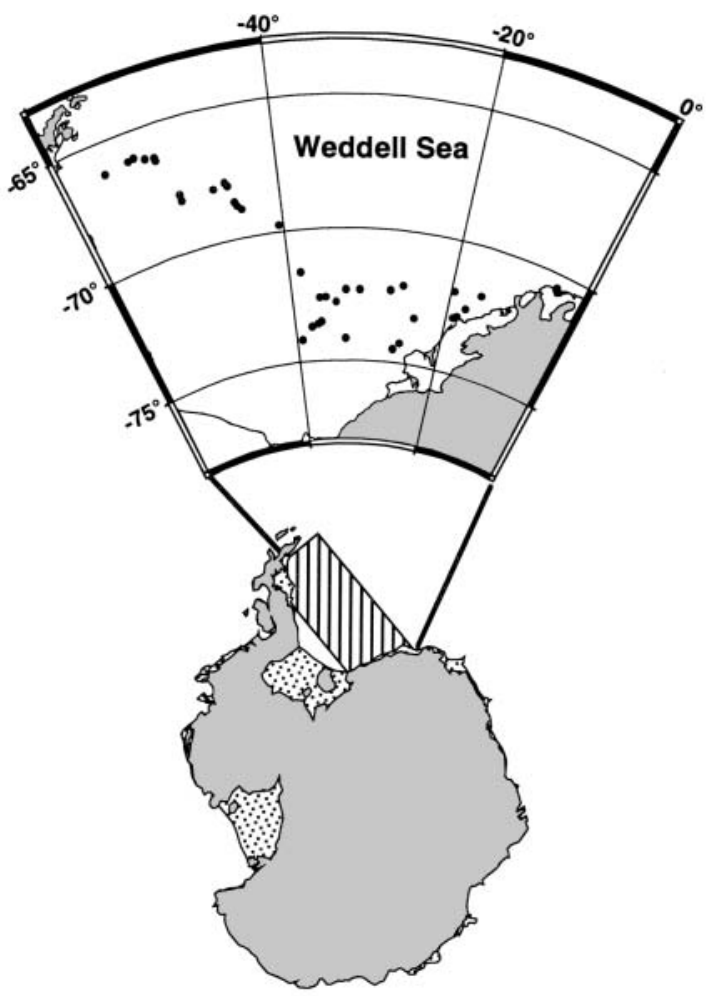

Fig. 1. Location of sampling sites (•) in the Weddell Sea, Antarctica
$\mathrm{CO}_{2}$ (aq), an increase in $\mu$ can also lead to smaller $\varepsilon_{\mathrm{p}}$ values (Francois et al. 1993, Laws et al. 1995).

Plankton in the open surface waters of the Southern Ocean are generally characterised by strongly negative $\delta^{13} \mathrm{C}_{\mathrm{POC}}$ (e.g. -21 to $-30 \%$ ) due to the low surface water temperatures and high $\left[\mathrm{CO}_{2}(\mathrm{aq})\right]$ (Rau et al. 1991a,b, Dehairs et al. 1997). Data from sea ice cores exhibit more positive values (Fischer 1991, Rau et al. 1991a) and are consistent with the hypothesis that $\left[\mathrm{CO}_{2}(\mathrm{aq})\right]$ is low in the sea ice. Large seasonal cycles in $\delta^{13} C_{\text {POC }}(-23$ to $-11 \%$ ) have also been observed in fast ice communities (Dunbar \& Levanter 1992), and the most positive $\delta^{13} \mathrm{C}_{\mathrm{POC}}$ were generally concurrent with the highest standing stock of POC within basal sea ice. Isotopic changes of similar magnitude have also been observed in sediment traps deployed under sea ice (Gibson et al. 1999) and over vertical gradients from the ice-water interface in ice cores (McMinn et al. 1999).

In closed or semi-closed environments, changes in the isotopic composition of $\sum \mathrm{CO}_{2}$ (i.e. $\delta^{13} \mathrm{C}_{\Sigma \mathrm{CO}_{2}}$ ) should also to be taken into account as the isotope fractionation during the fixation of carbon causes the remaining $\delta^{13} \mathrm{C}_{\mathrm{\Sigma CO}_{2}}$ to become more positive. There are few $\delta^{13} \mathrm{C}_{\Sigma \mathrm{CO}_{2}}$ data from sea ice environments. Reported values from platelet ice layers of 0.4 to $3.8 \%$ (Thomas et al. 2001), and from the water column of -0.5 to $2.5 \%$ o during an annual study including observations from below sea ice (Gibson et al. 1999), have shown $\delta^{13} \mathrm{C}_{\Sigma \mathrm{CO}_{2}}$ to vary with $\Sigma \mathrm{CO}_{2}$ depletion. These changes represent growth in a semi-closed environment and are observed when there is minimal replenishment of $\mathrm{\Sigma CO}_{2}$ from either atmospheric exchange, advective exchange or in situ remineralisation (Rau et al. 1992). Sea ice algae grown in bottles, to simulate a closed environment, resulted in strong reductions in $\left[\mathrm{CO}_{2}(\mathrm{aq})\right]$ and changes

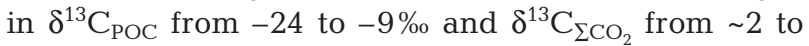
$10 \%$, with the more positive values representing samples taken during log phase growth (Gleitz 1996a).

Here, we report on stable carbon isotopic data from ice cores and water samples collected from a range of sea ice habitats in the Weddell Sea, Antarctica, during the late austral summer. The aims of this study were to provide a new, extensive data set of $\delta^{13} \mathrm{C}_{\mathrm{POC}}$ with which to confirm that positive isotope values are associated with algal POC derived from sea ice. We also investigated whether the isotope data are consistent with the suggestion that the ice habitat resembles a closed environment.

\section{MATERIALS AND METHODS}

Study sites. In January and February 1997, studies on sea ice were carried out during the ANT-XIV/3 
expedition of RV 'Polarstern' to the Weddell Sea (Fig. 1). A range of ice types and features associated with late summer sea ice were sampled during this study. A detailed description of the ice conditions and sampling is given by Haas et al. (1998). Summer conditions prevailed during the first $2 / 3$ of the expedition, with air temperatures around $0^{\circ} \mathrm{C}$. Both intact and layered ice floes occurred. A characteristic of the layered floes was a quasi-continuous horizontal gap in the ice, at or shortly below the water level (Fig. 2). Surface ice layers, consisting of solid slabs of low salinity ice and metamorphic snow, were underlain by gaps that were filled with seawater. The formation and development of these gap layers has been discussed by Haas et al. (2001). The base of this surface ice layer was often very porous and saline. The mean surface layer and gap thicknesses were 7 to $20 \mathrm{~cm}$ and 4 to $8 \mathrm{~cm}$, respectively (Haas et al. 2001). The ice layer below the gap generally consisted of very rotten sea ice. Surface ponds around pressure ridges and on level ice were also encountered. These surface features can be formed by seawater inundation and/or melting events. The depth of the ponds can increase with melting and eventually form contact with the underlying seawater (Ackley \& Sullivan 1994). When surface melting occurs, the low density fresh water will eventually become mixed with the more saline waters below leading to surface ponds that exhibit a range of salinities.

Sampling. The sampling techniques employed are summarised below and are more fully described by Schnack-Schiel et al. (2001). Open water was collected from the edges of ice floes during ice sampling. Using standard ice coring techniques, ice cores were collected from both floes with no evidence of sub-surface gaps (intact floes) and from those with gap layers (layered floes). Gap waters from layered floes were sampled after coring of the surface ice and metamorphic snow by immersing bottles or $0.5 \mathrm{dm}^{-3}$ plastic containers directly into the water. Surface ponds were also sampled by immersing plastic containers directly into the water. Generally, samples were taken from the edge of the ponds, although on occasions they were taken from the centre or from the top, mid and bottom of the pond.

Immediately after coring, ice cores $(10 \mathrm{~cm}$ in diameter) were divided into $10 \mathrm{~cm}$ sections with a clean stainless steel saw, and placed in $1 \mathrm{dm}^{-3}$ opaque PVC containers. On board ship, the ice sections were melted in the containers at $4^{\circ} \mathrm{C}$ in the dark. This process took no longer than $24 \mathrm{~h}$ due to the porous nature of the ice. Sub-samples of water and melted core sections were filtered through precombusted GF/F filters (Whatmann, $450^{\circ} \mathrm{C}, 3 \mathrm{~h}$ ). Filters were stored frozen $\left(-20^{\circ} \mathrm{C}\right)$ for particulate organic carbon/particulate organic nitrogen (POC/PON) and $\delta^{13} \mathrm{C}_{\mathrm{POC}}$ analysis. The filtrate was poisoned with $\mathrm{HgCl}_{2}$ and stored at $4{ }^{\circ} \mathrm{C}$ in $0.05 \mathrm{dm}^{-3}$ polyethylene bottles for later inorganic nutrient analyses (Kattner 1999).

Analytical methods. Gap waters and open water samples were analysed immediately for in situ temperature, salinity, $\left[\mathrm{O}_{2}\right], \mathrm{pH}$ and alkalinity, as described by Gleitz et al. (1995) and Günther et al. (1999). The carbonate system was calculated from $\mathrm{pH}$ and alkalinity using the carbonic acid dissociation constants of Mehrbach et al. (1973) and $\left[\mathrm{CO}_{2}(\mathrm{aq})\right]$ was calculated for a temperature of $0^{\circ} \mathrm{C}$. Additional samples were collected for $\delta^{13} \mathrm{C}_{\Sigma \mathrm{CO}_{2}}$, which were filtered through $0.45 \mu \mathrm{m}$ polycarbonate filters. The filtrates were poisoned with $\mathrm{HgCl}_{2}$ and sealed in pre-weighed glass ampoules under nitrogen.

Inorganic nutrient analyses were performed using standard autoanalyser methods (Kattner \& Becker 1991). Filters for POC/PON and $\delta^{13} C_{\mathrm{POC}}$ were acid fumed (concentrated $\mathrm{HCl}$ ) overnight to remove carbonate, dried at $40^{\circ} \mathrm{C}$ and then stored in a desiccator prior to analysis. [POC/PON] were determined with a Europa Scientific $\mathrm{CN}$ analyser, using acetanilide as a standard. Samples for $\delta^{13} \mathrm{C}_{\mathrm{POC}}$ analysis were processed and subsequently analysed as described by Kennedy \& Robertson (1995) using VG SIRA II and PDZ-EUROPA 20/20 isotope ratio mass spectrometers. Samples for $\delta^{13} \mathrm{C}_{\Sigma \mathrm{CO}_{2}}$ were processed as described by McCorkle (1987). The isotopic composition of $\mathrm{CO}_{2}$ (aq) (i.e. $\left.\delta^{13} \mathrm{C}_{\mathrm{CO}_{2}(\mathrm{aq})}\right)$ was determined from $\delta^{13} \mathrm{C}_{\Sigma \mathrm{CO}_{2}}$ and absolute temperature ( $\mathrm{T}_{\mathrm{k}}$ in Kelvin) using the equation $\delta^{13} \mathrm{C}_{\mathrm{CO}_{2} \text { (aq) }}=\delta^{13} \mathrm{C}_{\mathrm{\Sigma CO}_{2}}+23.644-9701.5 / \mathrm{T}_{\mathrm{k}}$ from Burkhardt et al. (1999). Isotopic fractionation was calculated relative to $\mathrm{CO}_{2}$ as a carbon source $\varepsilon_{\mathrm{p}}=\left(\delta^{13} \mathrm{C}_{\mathrm{CO}_{2} \text { (aq) }}\right.$ $\left.\delta^{13} \mathrm{C}_{\mathrm{POC}}\right) /\left(1+0.001 \delta^{13} \mathrm{C}_{\mathrm{POC}}\right)$. The carbon isotope ratios are expressed in the standard $\delta^{13} \mathrm{C}(\%)$ notation relative to $\mathrm{PDB}$, with a precision (including sample collection and extraction) of $\pm 0.1 \%$ for both $\delta^{13} \mathrm{C}_{\mathrm{POC}}$ and $\delta^{13} \mathrm{C}_{\mathrm{\Sigma CO}_{2}}$.

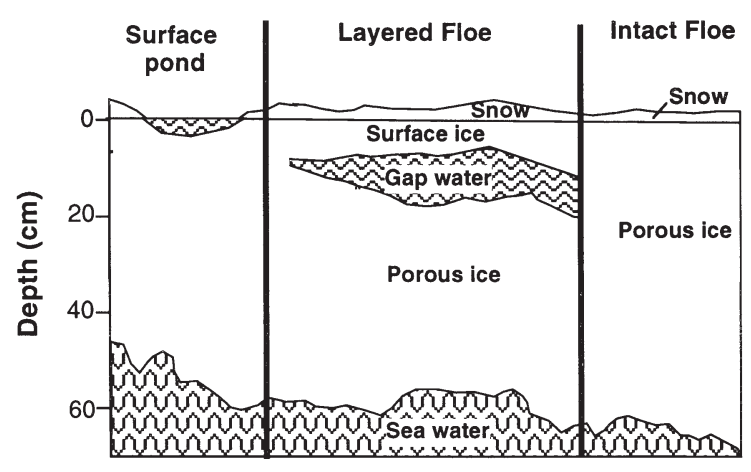

Fig. 2. Schematic illustration of ice habitats associated with summer sea ice 
Table 1. Salinity, particulate organic carbon and nitrogen (POC and PON) concentration, C:N ratio and the stable isotopic composition of the POC and $\sum \mathrm{CO}_{2}$ (mean $\pm 1 \sigma$ ) for all samples. nd $=$ not determined

\begin{tabular}{|c|c|c|c|c|c|c|c|c|}
\hline & $\begin{array}{c}\text { No. of } \\
\text { samples }\end{array}$ & $\begin{array}{c}\text { Bulk } \\
\text { salinity }\end{array}$ & $\begin{array}{c}\mathrm{POC} \\
\left(\mathrm{nmol} \mathrm{dm}^{-3}\right)\end{array}$ & $\begin{array}{c}\mathrm{PON} \\
\left(\mathrm{nmol} \mathrm{dm}^{-3}\right)\end{array}$ & $\mathrm{C}: \mathrm{N}$ & C:chl a & $\begin{array}{c}\delta^{13} \mathrm{C}_{\mathrm{POC}} \\
(\%)\end{array}$ & $\begin{array}{c}\delta^{13} \mathrm{C}_{\Sigma \mathrm{CO}_{2}} \\
(\%)\end{array}$ \\
\hline Seawater & 4 & $31.2 \pm 0.1$ & $17 \pm 8$ & $3 \pm 1.2$ & $5.6 \pm 0.5$ & $211 \pm 66$ & $-26.1 \pm 1.4$ & 2.1 \\
\hline Intact floes & 91 & $4.5 \pm 2.0$ & $175 \pm 240$ & $19.3 \pm 23.6$ & $9.5 \pm 5.6$ & $1262 \pm 2276$ & $-21.9 \pm 3.0$ & nd \\
\hline \multicolumn{9}{|l|}{ Layered floes } \\
\hline At ice/water interface & 21 & $9.3 \pm 2.3$ & $1801 \pm 1971$ & $215 \pm 212$ & $7.8 \pm 1.6$ & & $-20.1 \pm 2.2$ & nd \\
\hline Above ice/water interface & 57 & $8.0 \pm 2.6$ & $417 \pm 382$ & $58 \pm 86$ & $8.9 \pm 2$ & & $-19.8 \pm 2.9$ & nd \\
\hline Overall & 78 & $8.3 \pm 2.9$ & $837 \pm 1298$ & $98.3 \pm 145$ & $8.6 \pm 2$ & $284 \pm 351$ & $-19.9 \pm 3.0$ & nd \\
\hline Gap water & 35 & $29.3 \pm 2.6$ & $126 \pm 117$ & $17.6 \pm 16$ & $6.9 \pm 1$ & $321 \pm 415$ & $-22.4 \pm 2.0$ & $1.7 \pm 1.1$ \\
\hline Surface ponds & 26 & $16.2 \pm 8.9$ & $160 \pm 159$ & $18.1 \pm 17.4$ & $8.6 \pm 3.1$ & $605 \pm 555$ & $-19.5 \pm 1.7$ & $1.3 \pm 0.6$ \\
\hline
\end{tabular}

\section{RESULTS}

\section{Salinity}

The salinity of all samples varied from 0.4 to 31.3 (for means see Table 1). Ice cores from intact ice floes and the surface ice layer of layered floes generally had low bulk salinities ranging from 0.4 to 10.4 and 0.4 to 12.9 , respectively. The highest salinities in this set were those from the ice-water boundary, which is at $\sim 10 \mathrm{~cm}$ for the surface ice layer of the layered floes, but much deeper at 50 to $250 \mathrm{~cm}$ in the intact floes (Fig. 3). The gap waters, below the surface ice layer of layered floes, had relatively high salinities ranging from 20.6 to 31.3. These values were generally lower than those measured in seawater collected near the ice floes $(31.2$ to 31.4$)$. The surface ponds exhibited the widest range in salinity (3.4 to 30.9 ).

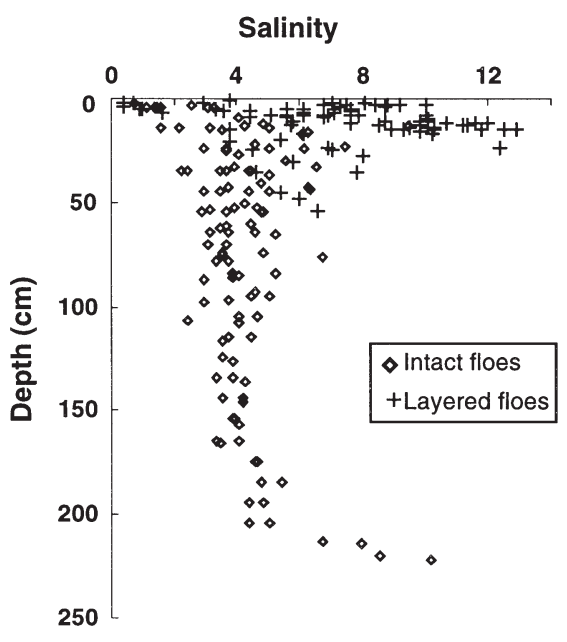

Fig. 3. Depth profiles of salinity in ice from intact and layered floes

\section{Particulate organic matter}

The [POC] (Fig. 4A) ranged over 3 orders of

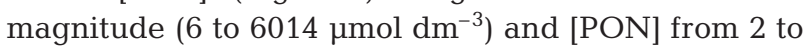
$616 \mu \mathrm{mol} \mathrm{dm}{ }^{-3}$ (Fig. 4B). [POC] in intact (32.5 to 1582

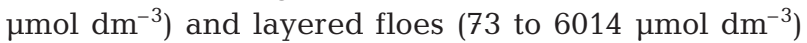

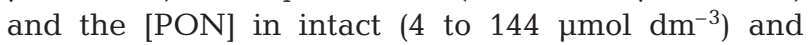
layered floes $\left(10\right.$ to $\left.616 \mu \mathrm{mol} \mathrm{dm}^{-3}\right)$ increased logarithmically with salinity (Fig. 4A,B). The highest

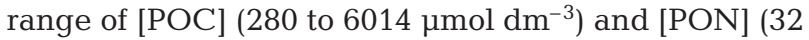

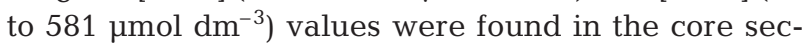
tions at the ice-water boundary (Table 1). The gap waters (9 to $424 \mu \mathrm{mol} \mathrm{dm}{ }^{-3}$ ) and surface ponds (8.3 to $527 \mathrm{mmol} \mathrm{dm}^{-3}$ ) had lower [POC], but were higher than those measured in the seawater (9 to $25 \mu \mathrm{mol} \mathrm{dm}{ }^{-3}$ ) taken near the ice floes. Gap water, surface ponds and open waters had [PON] ranges of 2 to 62,1 to 60 and $<1$ to $5.2 \mu \mathrm{mol} \mathrm{dm}{ }^{-3}$, respectively.

Although the variability in [POC] and [PON] was very high between the sample sites (Table 1), there were only small differences in the POC:PON ratios (Table 1). The average value of all samples (7.6) was slightly higher than the Redfield ratio (6.5), but is still consistent with the majority of the POM representing biogenic material rather than an accumulation of aged detritus material. A more common measure for living photosynthetic assemblages is chl $a$ and this can be related to POC through the POC:chl a ratio. The POC:chl a ratios reported for algae in culture vary from 10 to 100 s (Geider et al. 1997). Chl a data from all the collected samples (D. N. Thomas unpubl. data) have been used to calculate POC:chl a ratios (Table 1). The mean POC:chl a ratios are higher than those reported for algal cultures (Geider 1997) and suggest a variable, additional component of non-photosynthetic POC.

In all sample types, the range of $\delta^{13} C_{\mathrm{POC}}$ was very large, -27.3 to $-10.0 \%$ o (Fig. 5, Table 1). This is as large as the entire latitudinal trend observed in surface plankton (Rau et al. 1989) and the absolute values 

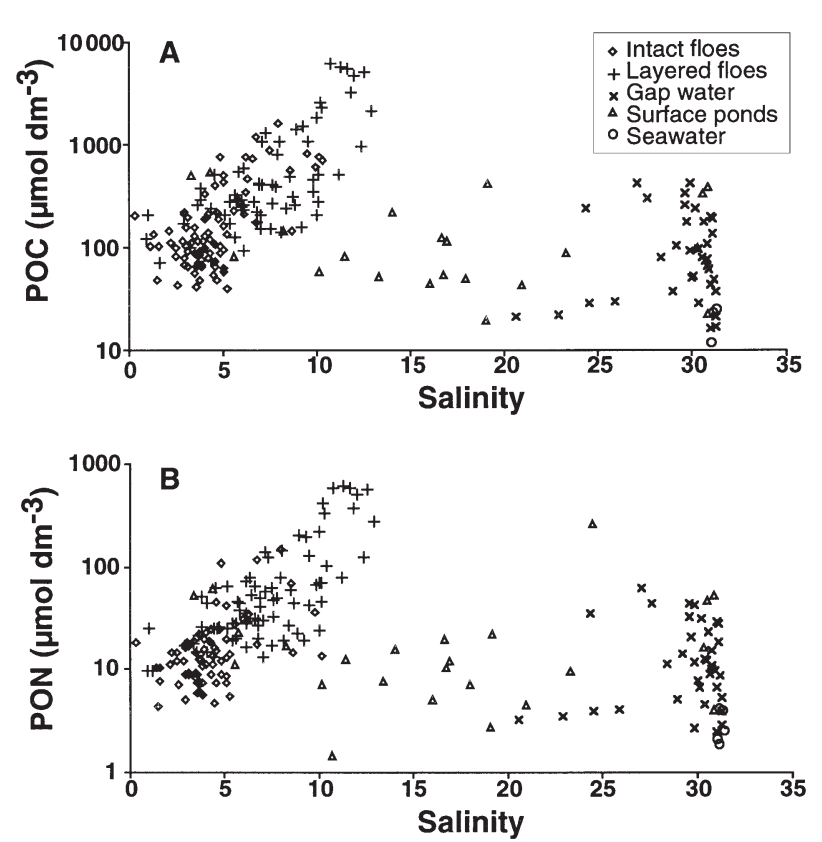

Fig. 4. (A) Particulate organic carbon (POC) and (B) particulate organic nitrogen (PON) concentrations in sea ice as a function of salinity. Note the log scale for both of the $y$-axes

were all more positive than open water plankton communities in the Antarctic (Rau et al. 1991a,b, Kennedy \& Robertson 1995, Dehairs et al. 1997). The $\delta^{13} \mathrm{C}_{\mathrm{POC}}$ ranges measured in cores from intact ( -26.6 to $-11.9 \%$ ) and the surface layer of the layered floes $(-25.0$ to $-10.0 \%$ ) were of similar magnitude. The gap waters from the layered floes had $\delta^{13} \mathrm{C}_{\mathrm{POC}}$ values of -26.3 to $-16.5 \%$, the surface ponds -22.8 to $-14.4 \%$ and seawater close to the floes -23.5 to $-27.3 \%$. The majority of the samples had been collected from either high or low salinity environments, reflecting open waters and the interior of ice floes. Although they represent very different environmental settings, the ranges in $\delta^{13} \mathrm{C}_{\mathrm{POC}}$ recorded were similar.

\section{Dissolved inorganic constituents}

The concentration of nitrate $\left(\left[\mathrm{NO}_{3}{ }^{-}\right]\right.$; Fig. 6) varied

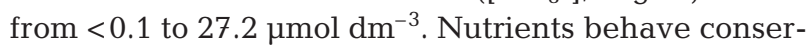
vatively during freezing and melting of seawater and if this was the only process affecting their concentration the data would follow a linear distribution between seawater and fresh water. However, the majority of the $\mathrm{NO}_{3}{ }^{-}$data were well below this distribution and $\mathrm{NO}_{3}{ }^{-}$ was substantially depleted, even exhausted, in many of the samples. For example, 15 ponds displayed $\left[\mathrm{NO}_{3}{ }^{-}\right]$ $<0.7 \mu \mathrm{mol} \mathrm{dm}{ }^{-3}$ and 4 had no measurable $\mathrm{NO}_{3}{ }^{-}$at all (Fig. 6).

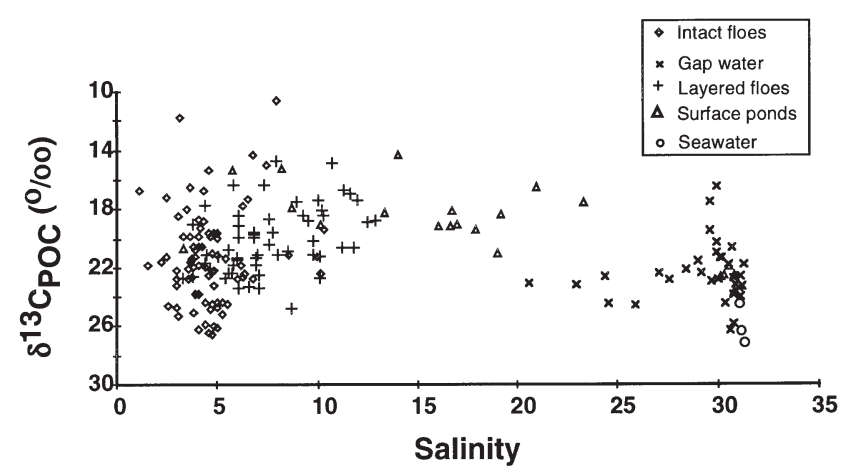

Fig. 5. Stable carbon isotopic composition of particulate organic carbon (POC) in sea ice as a function of salinity

In water collected from the gaps in layered floes and from the surface ponds, $\left[\Sigma \mathrm{CO}_{2}\right]$ ranged from 500 to $2160 \mu \mathrm{mol} \mathrm{dm}^{-3}$ (Fig. 7A). Because the $\left[\sum \mathrm{CO}_{2}\right]$ is high in seawater, its depletion in excess of dilution is not as clear as for $\mathrm{NO}_{3}{ }^{-}$, but the data still support a significant removal of $\sum \mathrm{CO}_{2}$. The variation of $\left[\mathrm{CO}_{2}(\mathrm{aq})\right]$ with salinity (Fig. $7 \mathrm{~B}$ ) exhibits a similar trend to $\left[\mathrm{NO}_{3}{ }^{-}\right]$. Concentrations below $5 \mu \mathrm{mol} \mathrm{dm}{ }^{-3}$ were encountered both in the gap waters and the surface ponds and very large depletions in $\left[\mathrm{CO}_{2}(\mathrm{aq})\right]$ were shown to occur over very small salinity ranges (e.g. 29 to 31). $\left[\mathrm{O}_{2}\right]$ varied from 337 to $583 \mu \mathrm{mol} \mathrm{dm}{ }^{-3}$ with highest concentrations where $\left[\mathrm{NO}_{3}^{-}\right]$and $\left[\mathrm{CO}_{2}(\mathrm{aq})\right]$ were lowest (Fig. $7 \mathrm{C}$ ). The distribution of $\delta^{13} \mathrm{C}_{\Sigma \mathrm{CO}_{2}}(0.15$ to $2.98 \%$ ) with salinity was similar to that of $\mathrm{O}_{2}$. The samples with a salinity close to that of seawater had variable $\delta^{13} \mathrm{C}_{\mathrm{ECO}_{2}}$ but included values in the same range as those reported for surface water $(\sim 1.1$ to $1.75 \%$ ) from the Weddell Sea

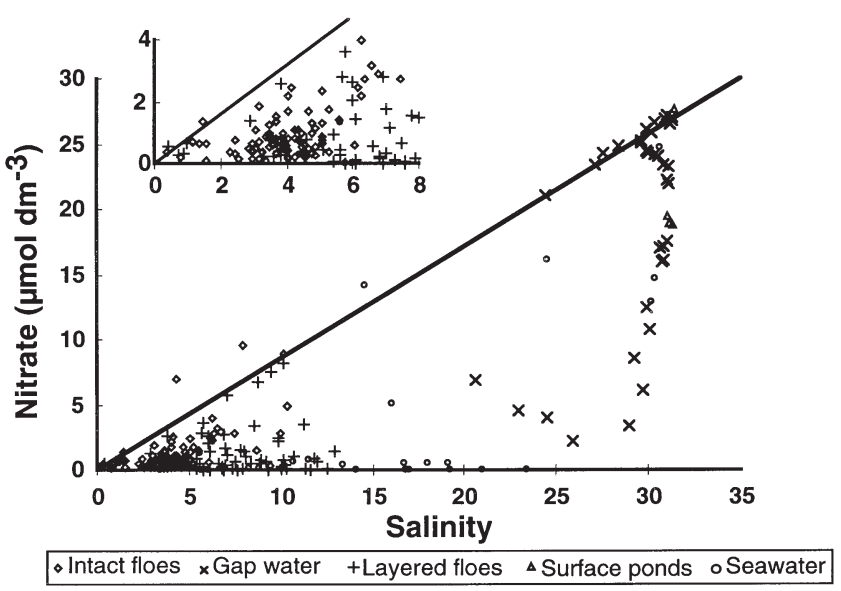

Fig. 6. $\mathrm{NO}_{3}{ }^{-}$concentrations in sea ice as a function of salinity. Solid line represents a dilution line with freshwater assuming an initial salinity of 34 and $\mathrm{NO}_{3}{ }^{-}$concentration of $32 \mu \mathrm{mol}$ $\mathrm{dm}^{-3}$. Inset expanded view of data for low salinity samples 


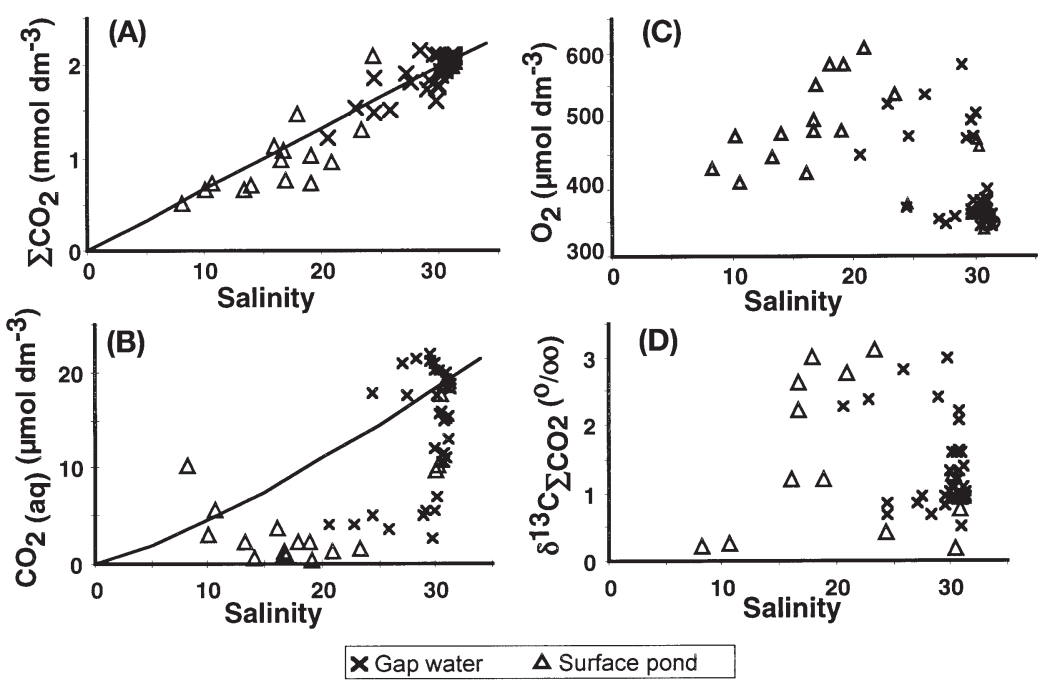

Fig. 7. (A) $\Sigma \mathrm{CO}_{2}$, (B) $\mathrm{CO}_{2}$ (aq), (C) dissolved $\mathrm{O}_{2}$ concentrations and (D) $\delta^{13} \mathrm{C}_{\Sigma \mathrm{CO}_{2}}$ as a function of salinity. Solid line represents changes expected if concentrations were affected solely by dilution with freshwater, assuming a salinity of 34 , alkalinity of $2391 \mu$ eq $\mathrm{dm}^{-3}, \mathrm{NO}_{3}{ }^{-}$of $32 \mu \mathrm{mol} \mathrm{dm}{ }^{-3}$ and $\sum \mathrm{CO}_{2}$ of $2240 \mu \mathrm{mol} \mathrm{dm}{ }^{-3}$

tween these variables, it suggests that there is little dependence of $\varepsilon_{\mathrm{p}}$ on carbon supply (Fig. 8).

\section{DISCUSSION}

The range of [POC] (6 to $6014 \mu \mathrm{mol}$ $\left.\mathrm{dm}^{-3}\right)$ and $\delta^{13} \mathrm{C}_{\mathrm{POC}}(-10.7$ to $-26.6 \%$ o) measured demonstrates the very variable and dynamic nature of sea ice. This variability may be due in large part to spatial differences in rates of nutrient supply relative to algal uptake. In an open environment, where nutrient replenishment is faster than algal demand, little/no drawdown of $\mathrm{NO}_{3}^{-}$or $\mathrm{CO}_{2}$ (aq) need be observed even if significant algal growth has occurred. Under these conditions, such as at the ice-water interface where algae are in direct contact with seawater, the continuous supply

during the austral summer (Gruber et al. 1999). Although the mean $\delta^{13} \mathrm{C}_{\mathrm{\Sigma CO}_{2}}$ values were similar for gap water and surface ponds, the variability was much higher in the former (Table 1).

\section{Dependence of $\varepsilon_{\mathrm{p}}$ on $\left[\mathrm{CO}_{2}(\mathrm{aq})\right]$}

A negative linear relationship is predicted for carbon isotopic fractionation $\left(\varepsilon_{\mathrm{p}}\right)$ as a function of the ratio of cellular carbon demand to carbon supply, $\mu /\left[\mathrm{CO}_{2}(\mathrm{aq})\right]$ for values <0.3 (Laws et al. 1997). Because growth rates could not be measured in this study, we can only assess $\varepsilon_{\mathrm{p}}$ variations in relation to the ambient $\left[\mathrm{CO}_{2}(\mathrm{aq})\right]$. As there is no significant correlation be-

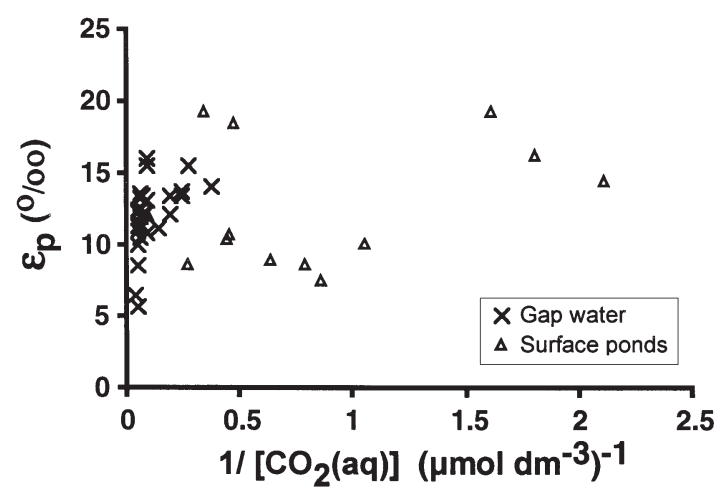

Fig. 8. Carbon isotopic fractionation, $\varepsilon_{\mathrm{p}}$ of particulate organic carbon (POC) versus the reciprocal of dissolved $\mathrm{CO}_{2}$ concentration of nutrients can lead to algal POC concentrations in excess of those predicted from the draw-down of $\mathrm{NO}_{3}{ }^{-}$in the underlying water.

If nutrient replenishment is slower than algal demand, draw-down of $\mathrm{NO}_{3}^{-}$and $\mathrm{CO}_{2}$ (aq) would become evident and the conditions would resemble that of a semi-closed environment. Even in open waters, stratification (thermal or density driven) can lead to algal growth in a semi-enclosed environment when algal demand for $\mathrm{NO}_{3}{ }^{-}$and $\mathrm{CO}_{2}(\mathrm{aq})$ is greater than their resupply by exchange, remineralisation and mixing.

In the brine channels of the sea ice, algae communities have essentially a fixed amount of $\mathrm{NO}_{3}^{-}$and $\mathrm{CO}_{2}$ (aq) to support growth as there is little or no external source of nutrients. Under these conditions, which can be considered as an isolated (essentially closed) system, $\left[\mathrm{NO}_{3}^{-}\right]$and $\left[\mathrm{CO}_{2}(\mathrm{aq})\right]$ will decrease until exhaustion or changes in the physiochemistry restrain further algal growth (Gleitz et al. 1995). In this case, algal demand can only be facilitated by the nutrient pool which is initially present and therefore the amount of algal growth will be limited. The maximum amount of POC that can be produced in a closed system can be estimated from the initial $\left[\mathrm{NO}_{3}{ }^{-}\right]$and the Redfield (C:N) ratio of 6.5. For example, if $1 \mathrm{dm}^{-3}$ of seawater froze and $10 \%$ of the ice volume comprised the brine channels, then the $\left[\mathrm{NO}_{3}^{-}\right]\left(\sim 32 \mu \mathrm{mol} \mathrm{dm}{ }^{-3}\right.$ in Antarctic seawater) would be concentrated into $0.1 \mathrm{dm}^{-3}$. If a $\mathrm{C}: \mathrm{N}$ ratio of 6.5 is used, the loss of $32 \mu \mathrm{mol}$ $\mathrm{NO}_{3}{ }^{-}$due to algal growth should result in the production of $\sim 208 \mu \mathrm{mol}$ POC. An even lower amount of POC 
would be produced if brine drainage had occurred. Salt is rejected from sea ice during the freezing process. Its loss occurs immediately at the ice-water interface and subsequently by drainage from the existing ice sheet as further accretion occurs (Lake \& Lewis 1970). This process does not change the $\left[\mathrm{NO}_{3}{ }^{-}\right]$in the brine channels, but it does reduce the amount of $\mathrm{NO}_{3}{ }^{-}$ that is available to the algae to sustain algal growth/ POC production. If $50 \%$ of the brine has been excluded from the ice, then the amount of $\mathrm{NO}_{3}{ }^{-}$now available for algal growth would be $16 \mu \mathrm{mol}$ which would result in a maximum of $\sim 104 \mu \mathrm{mol}$ POC produced on $\mathrm{NO}_{3}{ }^{-}$exhaustion. Thus, a comparison between $\mathrm{NO}_{3}{ }^{-}$draw-down and POC increase can be used to clearly illustrate the spatial differences in the rate of nutrient replenishment relative to algal demand.

Along with $\mathrm{NO}_{3}^{-}$draw-down, the photosynthetic uptake of dissolved inorganic carbon results in a decrease in $\left[\mathrm{CO}_{2}(\mathrm{aq})\right]$. Any reduction in $\left[\mathrm{CO}_{2}(\mathrm{aq})\right]$ will be reflected in more positive $\delta^{13} \mathrm{C}_{\mathrm{POC}}$ of the algae (Rau et al. 1992, Popp et al. 1999). The $\delta^{13} \mathrm{C}_{\mathrm{POC}}$ data further illustrate the degree of $\mathrm{NO}_{3}{ }^{-}$and $\mathrm{CO}_{2}(\mathrm{aq})$ draw-down, i.e. the balance between nutrient supply and demand when the majority of the POC was produced.

\section{Ice cores from intact and layered ice floes}

To observe the possible influence of algal growth on nutrients in ice floes, all the measured $\left[\mathrm{NO}_{3}{ }^{-}\right]$were salinity normalised to correct for dilution effects and the salinity normalised $\left[\mathrm{NO}_{3}^{-}\right]\left(\mathrm{SNO}_{3}{ }^{-}\right)$were subsequently related to [POC] (Fig. 9). The [POC] values for the communities at the ice-water interface of the surface ice in the layered floes exhibited a logarithmic increase in [POC] with decreasing $\left[\mathrm{SNO}_{3}{ }^{-}\right]$(Fig. 9A). The data lie on, or above, the line that defines the maximum [POC] that could be produced by algal growth in a closed system and represent semi- to open environments. Ice at the bottom of the surface ice layer in the layered floes had an average bulk salinity of $9.3 \pm 2.3$, as compared to an average bulk salinity of $4.5 \pm 2.0$ for intact ice floes, and was porous at the temperatures encountered facilitating nutrient exchange. If the ice algae mainly utilise $\mathrm{NO}_{3}{ }^{-}$diffusing from the underlying gap water, then the $\left[\mathrm{sNO}_{3}{ }^{-}\right]$in the ice can be viewed as the current balance between the rate of nitrogen $(\mathrm{N})$ replenishment and algal uptake. The diffusive flux of nutrients from the underlying water to the ice and nutrient regeneration represent 2 possible mechanisms for $\mathrm{N}$ supply to the ice algae at the icewater interface. Other mechanisms for enhancing the flux of $\mathrm{N}$ are through turbulence in or advection of the underlying water and by the pumping of seawater by wind/wave action. High algal standing stocks have been reported in other ice environments where water exchange or nutrient regeneration allows replenishment of nutrients while the ice provides a physical support for the algae to be retained within its matrix (Fritsen et al. 1994, Thomas et al. 1998).

In all the other ice core sections taken from the upper ice layer of the layered floes, the [POC] $(\sim 100$ to $2000 \mu \mathrm{mol} \mathrm{dm}^{-3}$ ) are 3 to 6 times lower than those at the ice/water interface (Fig. 9B). The POC data for these samples are mostly above the line predicted for algal growth in a closed system and generally lie below the logarithmic trend that described algal growth in the more open environment at the ice-water boundary (Fig. 9A). There may have been little or no nutrient addition to the brine channels during freezing as the upper ice layer of the layered floes is derived from molten snow. Therefore, the major source of nutrients to the algae in this part of the floe would then have been via the ice-water interface. For algae in the
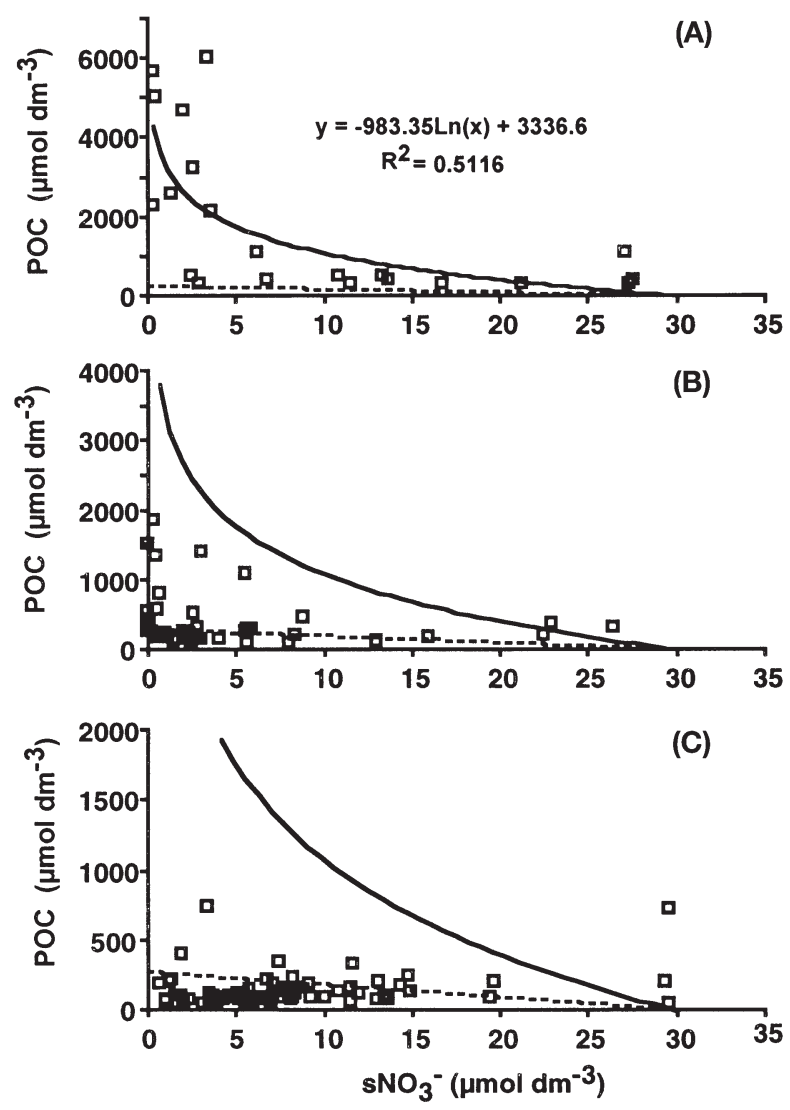

Fig. 9. Particulate organic carbon (POC) as a function of salinity normalised $\mathrm{NO}_{3}^{-}\left(\mathrm{sNO}_{3}^{-}\right)$. (A) Data from the ice-water interface of cores collected from the layered floes. (B) All other data from ice cores collected from the layered floes. (C) Data from cores collected from intact ice floes. The solid line is the regression line of the data in Fig. 9A and the dotted line denotes the trend for $\mathrm{NO}_{3}{ }^{-}$uptake if growth occurred in a closed system. Note the different scales for the POC axes 
brine channels some distance away from the ice-water interface, the flux of $\mathrm{N}$ is reduced by a progressive decrease in ice porosity, an increase in distance from the nutrient source and a reduction in [N] due to uptake of the algae nearer the ice/water interface.

All the POC measurements in core sections taken from within intact ice floes were less than $1000 \mu \mathrm{mol}$ $\mathrm{dm}^{-3}$ (Fig. 9C). In these, predicted to be the most isolated communities, there will be little/no diffusive supply of nutrients and POC production is limited due to their growth in a closed system. In fact, the majority of the [POC] fall below the predicted maximum for a closed system and, possibly, brine drainage has reduced the net amount of $\mathrm{NO}_{3}{ }^{-}$that is available for POC production. The $\mathrm{NO}_{3}{ }^{-}$and POC data have illustrated that the potential for biomass accumulation de-

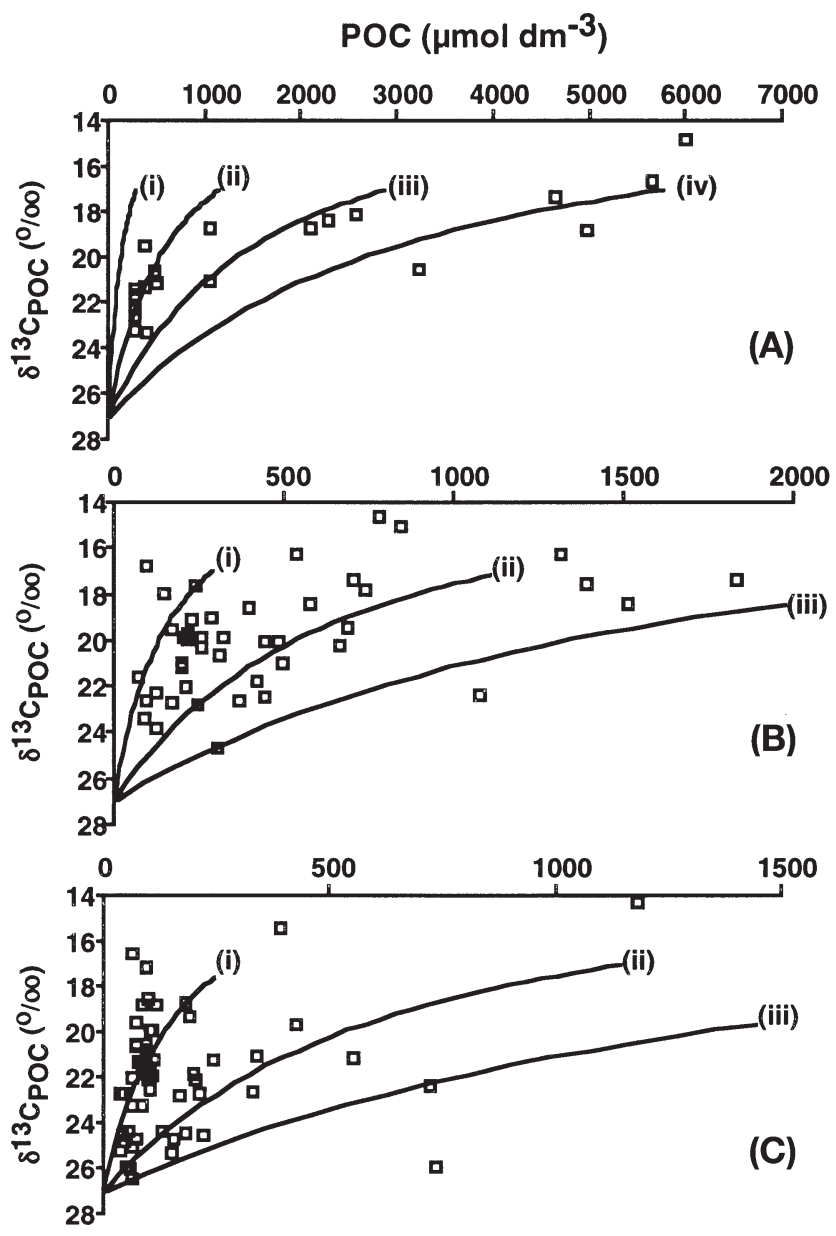

Fig. 10. $\delta^{13} \mathrm{C}_{\mathrm{POC}}$ as a function of particulate organic carbon (POC). Data are separated in the same manner as in Fig. 9. Solid lines labelled i to iv are the calculated trends that represent the changes in (i) a closed system and (ii) to (iv) in semienclosed/open environments where nutrient replenishment is possible and algal biomass exceeds any apparent nutrient depletion in the gap water by 4 (ii), 10 (iii) and 20 (iv) times the biomass possible in a closed environment creases in moving from an open (ice-water interface), to a closed (ice floe interior) environment.

Although $\left[\mathrm{CO}_{2}(\mathrm{aq})\right]$ was not measured in the melted sections of ice cores, the $\delta^{13} \mathrm{C}_{\mathrm{POC}}$ can be used as a proxy for $\left[\mathrm{CO}_{2}(\mathrm{aq})\right]$ to examine the balance between nutrient supply and demand, i.e. the steady state $\left[\mathrm{NO}_{3}{ }^{-}\right]$and $\left[\mathrm{CO}_{2}(\mathrm{aq})\right]$ maintained during major biomass production. In a similar way to our calculation of the amount of POC that can be produced with a concurrent drawdown of $\mathrm{NO}_{3}^{-}$in a closed environment, we can estimate the changes in $\delta^{13} \mathrm{C}_{\mathrm{POC}}$ from $\mathrm{sNO}_{3}{ }^{-}$without direct recourse to measurements of $\left[\mathrm{CO}_{2}(\mathrm{aq})\right]$. If we assume constant values for salinity and temperature and appropriate stoichiometry for algal growth, the initial concentrations for alkalinity, $\Sigma \mathrm{CO}_{2}$ and $\mathrm{NO}_{3}{ }^{-}, 2391 \mu \mathrm{eq}$ $\mathrm{kg}^{-1}, 2240 \mu \mathrm{mol} \mathrm{dm}{ }^{-3}$ and $32 \mu \mathrm{mol} \mathrm{dm}{ }^{-3}$, respectively, can be used to calculate the decrease of $\left[\mathrm{CO}_{2}(\mathrm{aq})\right]$ with degree of $\mathrm{NO}_{3}{ }^{-}$utilisation. The change in $\left[\sum \mathrm{CO}_{2}\right]$ has been assumed to be related to $\mathrm{NO}_{3}{ }^{-}$loss through a $\mathrm{C}: \mathrm{N}$ ratio of 9 , which is the average POC:PON for the sea ice samples, and the alkalinity has been taken to increase by $1 \mu \mathrm{eq} \mathrm{kg}^{-1}$ for every mole of $\mathrm{NO}_{3}^{-}$consumed. We can then predict $\delta^{13} \mathrm{C}_{\mathrm{POC}}$ from $\left[\mathrm{CO}_{2}(\mathrm{aq})\right]$ using an empirical relationship derived from observations in a Southern Ocean setting, $\delta^{13} \mathrm{C}_{\mathrm{POC}}=$ $-0.59\left[\mathrm{CO}_{2}(\mathrm{aq})\right]$ - 14.38. (Bentaleb \& Fontugne 1998). This approach assumes that $\mathrm{CO}_{2}(\mathrm{aq})$ has been the major influence on the $\delta^{13} \mathrm{C}_{\mathrm{POC}}$ of phytoplankton (Popp et al. 1999), but it is recognised that numerous additional factors e.g. growth rate, type of carboxylating enzyme, passive and/or active carbon transport, ammonia assimilation and $\delta^{13} \mathrm{C}_{\mathrm{CO}_{2}}$ can also have an influence on $\delta^{13} \mathrm{C}_{\mathrm{POC}}$ (Francois et al. 1993, Laws et al. 1995, Dehairs et al. 1997).

Using this approach for algal growth in a closed environment, $\delta^{13} \mathrm{C}_{\mathrm{POC}}$ becomes more positive $(-27$ to $-17 \%$ ) while [POC] increases (0 to $288 \mu \mathrm{mol} \mathrm{dm}^{-3}$ ). However, it has already been shown that not all samples are characteristic of growth in a closed environment. In the case of semi-enclosed environments, the differing balances between a nutrient flux and algal uptake can result in a variable steady state $\left[\mathrm{NO}_{3}{ }^{-}\right]$and hence $\left[\mathrm{CO}_{2}(\mathrm{aq})\right]$. In these cases, the range of possible steady state $\left[\mathrm{CO}_{2}(\mathrm{aq})\right]$ are the same as in the closed system and so the predicted range of $\delta^{13} \mathrm{C}_{\mathrm{POC}}$ remains the same. However, higher algal POC can be supported by remineralisation or a flux of nutrients from the surrounding water column in open or semienclosed environments, than can be produced in closed systems. The Trend Lines (i) to (iv) as seen in Fig. 10 represent some, from the continuum of possible calculated responses, of $\delta^{13} \mathrm{C}_{\mathrm{POC}}$ to decreasing $\left[\mathrm{CO}_{2}(\mathrm{aq})\right]$. The $\delta^{13} \mathrm{C}_{\mathrm{POC}}$ data (Fig. 10) have been divided into the same sample grouping as displayed in Fig. 9 and are presented as a function of measured [POC]. 
The measured values of $\delta^{13} \mathrm{C}_{\mathrm{POC}}$ from core sections at the ice-water boundary in layered ice floes (Fig. 10A) all fall above the closed system trend line (i). The data falls on or around the Trend Lines ii to iv and is consistent with the previous interpretation of this data set (Fig. 9A) of open and semi-enclosed environments. As the samples were collected from a number of different floes ( $\mathrm{n}=15$ ) where supply and demand will vary, it is not surprising that the data do not fall on any particular trend line but spans a number of different trends. A major variable in determining the rate of nutrient replenishment will be the porosity of the ice and the salinity gives a good indication of which samples were from the most porous ice. The data falling on or around the Trend Lines (ii) and (iv) in Fig. 10A, do indeed relate to significantly different salinities of $8.2 \pm 2$ and $11.7 \pm 1$, respectively.

In the ice sections taken at an increasing distance from the ice-water boundary in both layered (Fig. 10B) and intact floes (Fig. 10C), most $\delta^{13} \mathrm{C}_{\mathrm{POC}}$ values were similar to those found in the more open environment of the ice-water boundary (Fig. 10A). Consistent with the [POC] and $\left[\mathrm{SNO}_{3}{ }^{-}\right]$interpretation, only the data from core sections at the interior of intact ice floes (Fig. 10C) fall on or near the closed system Trend Line (i). In these habitats, lower [POC] is found because of the more restrictive replenishment of nutrients, but the range of $\left[\mathrm{CO}_{2}(\mathrm{aq})\right]$ implied by the $\delta^{13} \mathrm{C}_{\mathrm{POC}}$ is not reduced.

A few $\delta^{13} \mathrm{C}_{\mathrm{POC}}$ values were more positive than in Fig. $10 \mathrm{~A}$ and could be indicative of lower $\left[\mathrm{CO}_{2}\right.$ (aq)] resulting from $\mathrm{N}$ limitation, i.e. algal growth with a $\mathrm{C}: \mathrm{N}$ ratio $>9$. Previous studies in fast ice have reported large increases in both C:N (up to 25$)$ and $\delta^{13} \mathrm{C}_{\mathrm{POC}}(-18$ to $-12 \%$ ) at increasing distances from the ice-water boundary. These changes have also been interpreted as representative of progressive nutrient limitation (Smith et al. 1990, Priscu \& Sullivan 1998, McMinn et al. 1999).

Thus, the assumption that the highest biomass of algae in sea ice will result in the most positive $\delta^{13} C_{\mathrm{POC}}$ values cannot be generally applied. The balance between uptake and supply defines the extent of $\mathrm{CO}_{2}$ (aq) draw-down and hence the $\delta^{13} \mathrm{C}_{\mathrm{POC}}$ of the algae, and this can vary independently of the biomass accumulated.

\section{Gap water}

Substantial depletions in $\left[\mathrm{NO}_{3}{ }^{-}\right]$relative to dilution were observed in the water that filled the gap layers (Fig. 6). However, the [POC] of the gap water varied independently of $\left[\mathrm{SNO}_{3}^{-}\right]$(Fig. 11). The [POC] values did not conform to the trends predicted for algal growth in a closed environment using a POC:PON of either 6.9 or 7.8 , representative of gap water and the ice-water interface above the gap water, respectively (Table 1). The average [POC] of the gap water is $126 \pm$ $117 \mu \mathrm{mol} \mathrm{dm}{ }^{-3}$ (Table 1), which is much lower than that of the algal community in the ice at the ice-water boundary $\left(1801 \pm 1971 \mu \mathrm{mol} \mathrm{dm}^{-3}\right)$. The gap waters with $\sim 30 \mu \mathrm{mol} \mathrm{dm}{ }^{-3} \mathrm{SNO}_{3}^{-}$have [POC] that are very variable, but are all higher than would be predicted with considerable gains in [POC] with little or no loss of $\mathrm{NO}_{3}^{-}$(Fig. 11). In contrast, the remaining POC data from the gap water have concentrations that are well below those predicted with respect to loss of $\mathrm{NO}_{3}{ }^{-}$.

Substantial depletions in $\left[\mathrm{\Sigma CO}_{2}\right]$ relative to dilution and enrichments in $\left[\mathrm{O}_{2}\right]$ and $\delta^{13} \mathrm{C}_{\mathrm{SCO}_{2}}$ were also observed in the water that filled the gap layers (Fig. 7). By comparing changes in $\left[\mathrm{SNO}_{3}{ }^{-}\right]$to those of salinity normalised $\left(\left[\mathrm{sO}_{2}\right]\right.$ and $\left.\left[\mathrm{s} \sum \mathrm{CO}_{2}\right]\right)$ and $\delta^{13} \mathrm{C}_{\Sigma \mathrm{CO}_{2}}$ data (Fig. 12A,B,C), the extent to which the observed changes follow the stoichiometry of algal organic matter production can be examined.

Although $\left[\mathrm{s} \sum \mathrm{CO}_{2}\right]$ were variable at $\left[\mathrm{sNO}_{3}{ }^{-}\right] \sim 30 \mu \mathrm{mol}$ $\mathrm{dm}^{-3},\left[\mathrm{~s} \sum \mathrm{CO}_{2}\right]$ decreased with $\left[\mathrm{sNO}_{3}{ }^{-}\right]$overall, resulting in a $\sum \mathrm{CO}_{2} / \mathrm{NO}_{3}{ }^{-}$gradient of $11.5 \pm 1.3$ (Fig, 12A). This $\mathrm{C}: \mathrm{N}$ ratio is higher than that measured in the POM collected in the gap water (POC:PON $=6.9$ ) or in the ice at the interface with the gap water (POC:PON = 7.8), and are more consistent with nutrient limited algal growth. The $\left[\mathrm{O}_{2}\right]$ were generally invariant at high $\left[\mathrm{SNO}_{3}{ }^{-}\right]$but showed a significant increase at $\left[\mathrm{SNO}_{3}{ }^{-}\right]$lower than $\sim 17 \mu \mathrm{mol} \mathrm{dm}{ }^{-3}$ (Fig. 12B).

The $\delta^{13} \mathrm{C}_{\mathrm{ECO}_{2}}$ exhibited a significant negative correlation with $\left[\mathrm{sNO}_{3}^{-}\right], \delta^{13} \mathrm{C}_{\mathrm{LCO}_{2}}=-0.06 \pm 0.007 \mathrm{sNO}_{3}^{-}+$ $2.7 \pm 0.17, \mathrm{n}=34, \mathrm{R}^{2}=0.696$ (Fig. 12C). In closed or semi-closed environments, isotope fractionation during the fixation of carbon causes the remaining $\delta^{13} \mathrm{C}_{\mathrm{ECO}_{2}}$ to become more positive. To test whether the more positive $\delta^{13} \mathrm{C}_{\mathrm{\Sigma CO}_{2}}$ values were related to biological production, our previously calculated variations in

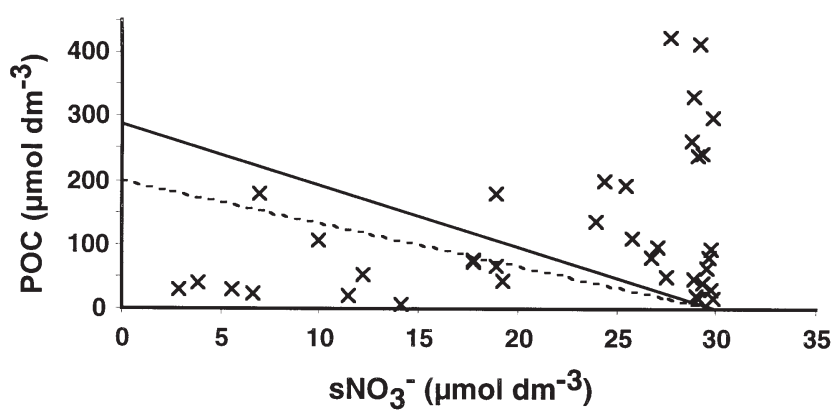

Fig. 11. Particulate organic carbon (POC) versus salinity normalised $\mathrm{NO}_{3}{ }^{-}\left(\mathrm{SNO}_{3}{ }^{-}\right)$of samples collected from gap waters. Model lines describing the changes expected if the trend in POC was defined by either a C:N ratio of 6.9 measured in organic matter from the gap water (dotted line), or 7.8 from the ice at the seawater interface in layered floes (solid line) 

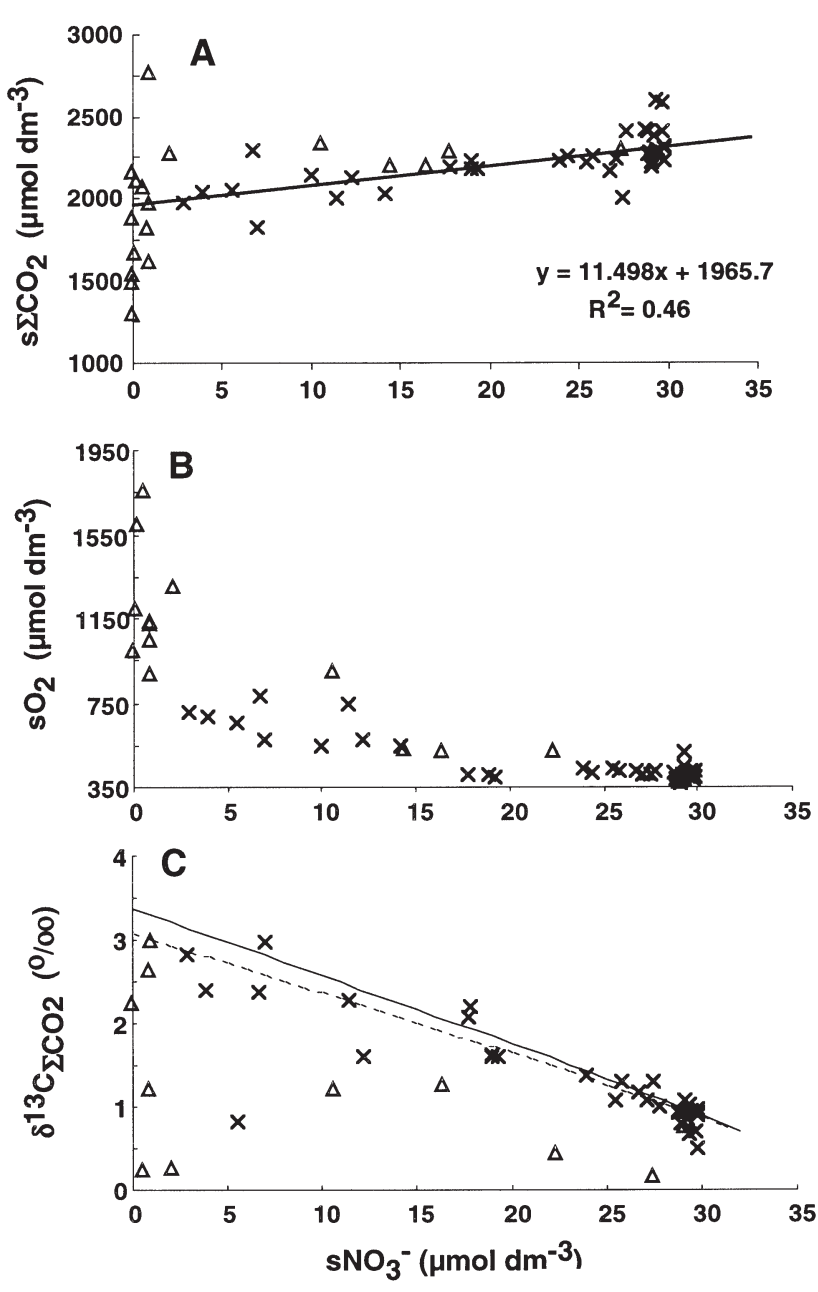

× Gap water $\Delta$ Surface pond

Fig. 12. $(\mathrm{A}, \mathrm{B})$ Salinity normalised $\mathrm{\Sigma CO}_{2}$ and $\mathrm{O}_{2}\left(\mathrm{~s} \Sigma \mathrm{CO}_{2}\right.$ and $\mathrm{sO}_{2}$ ), and (C) $\delta^{13} \mathrm{C}_{\Sigma \mathrm{CO}_{2}}$ of samples collected from gap water and surface ponds versus $\mathrm{SNO}_{3}{ }^{-}$. Solid line and equation in (A) represents the result of linear regression analysis of the gap water data. Lines in $(\mathrm{C})$ represent the expected trends in the gap water if the $\mathrm{C}: \mathrm{N}$ ratio is 6.9 (dotted line) or 7.8 (solid-line)

$\delta^{13} \mathrm{C}_{\mathrm{POC}}$, during algal growth in a closed system (Fig. 10 Trend Line i), have been used to predict changes in $\delta^{13} \mathrm{C}_{\Sigma \mathrm{CO}_{2}}$. The $\delta^{13} \mathrm{C}_{\Sigma \mathrm{CO}_{2}}$ of the remaining $\sum \mathrm{CO}_{2}$, $\left(\delta^{13} \mathrm{C}_{\Sigma \mathrm{CO}_{2}(t+1)}\right)$ has been predicted using a simple mass balance equation.

$$
\delta^{13} \mathrm{C}_{\Sigma \mathrm{CO}_{2}(t+1)}=f_{\mathrm{t}} \delta^{13} \mathrm{C}_{\Sigma \mathrm{CO}_{2}(t)}-f_{\text {uptake }} \delta^{13} \mathrm{C}_{\mathrm{POC}(\text { uptake) }}
$$

where $\delta^{13} \mathrm{C}_{\mathrm{POC}}\left(\right.$ uptake) represents the changing $\delta^{13} \mathrm{C}_{\mathrm{POC}}$ during algal growth in a closed system and becomes more positive at each time point as $\mathrm{NO}_{3}{ }^{-}$is taken up by the algae and $\left[\mathrm{CO}_{2}(\mathrm{aq})\right]$ decreases, $\delta^{13} \mathrm{C}_{\Sigma \mathrm{CO}_{2}(t)}$ is the isotopic composition of $\Sigma \mathrm{CO}_{2}$ of the preceding time point and $f_{\mathrm{t}}$ and $f_{\text {uptake }}$ are the fraction of $\Sigma \mathrm{CO}_{2}$ represented by the preceding time point and the fraction of the $\Sigma \mathrm{CO}_{2}$ removed by the algae. Predicted trend lines for POC:PON ratios of $6.9\left(\delta^{13} \mathrm{C}_{\Sigma \mathrm{CO}_{2}}=-0.074 \mathrm{sNO}_{3}{ }^{-}+3.1\right)$ representative of POM from gap water and $7.8\left(\delta^{13} \mathrm{C}_{\Sigma \mathrm{CO}_{2}}\right.$ $\left.=-0.083 \mathrm{sNO}_{3}{ }^{-}+3.4\right)$ representative of organic matter from the ice at the interface with the gap water have been compared to the actual $\delta^{13} \mathrm{C}_{\mathrm{CO}_{2}}$ variations in Fig. $12 \mathrm{C}$. If the single data point with a very low $\delta^{13} \mathrm{C}_{\mathrm{CO}_{2}}$ at $\left[\mathrm{sNO}_{3}{ }^{-}\right] \sim 5$ is excluded from the regression, then the trend line $\delta^{13} \mathrm{C}_{\mathrm{COO}_{2}}=-0.072 \pm 0.004 \mathrm{sNO}_{3}{ }^{-}+$ $3.02 \pm 0.11\left(n=33, R^{2}=0.895\right)$ is consistent with the observed changes due to biological production with a $\mathrm{C}: \mathrm{N}$ ratio of $\sim 6.9$. In contrast, these results are not wholly consistent with the observed $\mathrm{C}: \mathrm{N}$ ratio of 11 derived from changes in $\left[\mathrm{s} \Sigma \mathrm{CO}_{2}\right]$ and $\left[\mathrm{sNO}_{3}{ }^{-}\right]$(Fig. 12A).

Overall, the gap waters are strongly affected by the biological activity in the overlying ice. The substantial depletions in $\left[\mathrm{NO}_{3}{ }^{-}\right]$relative to dilution indicate that $\mathrm{N}$ uptake by the ice algae must be faster than the advection of seawater into the gap layers. Gap sites with less restricted exchange (or lower rates of uptake relative to supply) would show little evidence of nutrient depletion, even with high algal standing stocks in the over-lying ice. Similar results have been observed in platelet layers where there can be high biomass of algae $\left(1 \mathrm{~g} \mathrm{chl} \mathrm{a} \mathrm{dm}^{-3}\right)$ attached to the platelets with little or no measurable nutrient depletion in the water column (Thomas et al. 1998, Günther \& Dieckmann 1999). The lack of correlation between [POC] and [ $\left.\mathrm{SNO}_{3}{ }^{-}\right]$(Fig. 11) as well as $\varepsilon_{\mathrm{p}}$ and $1 /\left[\mathrm{CO}_{2}(\mathrm{aq})\right]$ (Fig. 8) may also be explained if the changes in dissolved constituents are more strongly influenced by the algae in the overlying ice than those found in the gap water, and the POM derives from both algal growth in the gap water and algal biomass that has been flushed out of the ice.

\section{Surface ponds}

The surface ponds were found on level ice and associated with pressure ridges. The ponds must have initially contained only seawater as their bottom was below the sea level. As the ponds reduce the albedo and increase light absorption, this leads to heating and melting of the surface snow and ice. The ponds subsequently become stratified, with melt water on top of more saline water. The vertical transport of nutrients into the surface waters may be limited, but the salinity range measured in the ponds ( 7 to 30 ) suggested that there must have been mixing of fresh and saline waters, and in the high salinity ponds the mixing must have been extensive. Swell, wind and/or drift can enhance vertical transport and mix the saline water up into the freshwater. Alternatively, flooding of the ice 
floe surfaces by seawater may have contributed to the salinity of the ponds. Thus, the surface ponds do not represent true closed systems because some degree of exchange has occurred.

Many of the ponds had little/no measurable $\left[\mathrm{NO}_{3}{ }^{-}\right]$ or $\left[\mathrm{CO}_{2}(\mathrm{aq})\right]\left(\right.$ mean $\left.=5.2 \pm 8.9 \mu \mathrm{mol} \mathrm{dm}{ }^{-3}, \mathrm{n}=28\right)$ and varied in salinity from 3.4 to 30.9 (Fig. 6). The concentrations of dissolved constituents reflect, in part, the variable salinity of the ponds. But because most ponds featured $\mathrm{NO}_{3}{ }^{-}$exhaustion, a salinity normalisation procedure to remove the effect of variable mixing of fresh and saline water could not be used. In addition, algal growth in the ponds would also result in low $\left[\mathrm{NO}_{3}{ }^{-}\right]$ and $\left[\mathrm{CO}_{2}(\mathrm{aq})\right]$. The salinity is taken to represent the amount of mixing that has occurred between freshwater (salinity $=0$ ) and seawater (salinity $=34$ ), If $\mathrm{NO}_{3}{ }^{-}$ behaved conservatively during this mixing, then an initial $\left[\mathrm{NO}_{3}{ }^{-}\right]$characteristic of the salinity of each pond can be estimated using a simple mixing equation. Using this approach and a seawater $\left[\mathrm{NO}_{3}{ }^{-}\right]$of $32 \mu \mathrm{mol}$ $\mathrm{dm}^{-3}$, the ponds should have $\left[\mathrm{NO}_{3}{ }^{-}\right]$ranging from 8 to $29 \mu \mathrm{mol} \mathrm{dm}{ }^{-3}$. The measured concentrations are much lower and have presumably been reduced by algal growth. The difference between the salinity predicted values $\left(\mathrm{NO}_{3}^{-}\right.$initial $)$and the concentration measured $\left(\mathrm{NO}_{3}{ }^{-}\right.$measured $)$in the pond at the time of sampling, should give an estimate of the amount of $\mathrm{NO}_{3}{ }^{-}$that has been removed $\left(\mathrm{NO}_{3}{ }^{-}\right.$deficit $)$by algal growth. The same approach, using seawater $\left[\sum \mathrm{CO}_{2}\right]=2240 \mu \mathrm{mol} \mathrm{dm}{ }^{-3}$, has been taken to estimate the $\left(\sum \mathrm{CO}_{2}\right.$ deficit $)$. Because there may still be some exchange possible with the underlying seawater these are likely to be minimum estimates.

The variation of $\mathrm{NO}_{3}{ }^{-}$deficit with $\sum \mathrm{CO}_{2}$ deficit indicates strong nutrient limitation in some of the surface ponds (Fig. 13A) with most of the data falling within those predicted by a C:N ratio of 6.5 or 30 . The data were collected from a number of different ponds $(n=13)$ and the scatter in the data suggests that the conditions in each of the ponds were slightly different at the time of sampling. Generally though, the ponds with highest $\mathrm{NO}_{3}{ }^{-}$deficit also had the highest $\sum \mathrm{CO}_{2}: \mathrm{NO}_{3}{ }^{-}$indicating $\mathrm{N}$ limitation. Analogous microenvironments have been described in crack pools associated with the release of melt water into pools of seawater trapped between melting ice floes (Gleitz et al. 1996b). The crack pools displayed $\mathrm{NO}_{3}{ }^{-}$exhaustion and were thought to have evolved due to rapid algal growth from an initially nutrient rich and high salinity pool, as the result of a batch-culture type of development.

If the ponds are essentially closed systems, then there should be similar $\mathrm{C}: \mathrm{N}$ ratios for the variation of $\mathrm{NO}_{3}{ }^{-}$deficit with [POC] (Fig. 13B). Although the data mainly fall between a $C: N$ ratio of 6.5 and 30 , the $C: N$ ratios are generally lower than those shown in Fig. 13A.
Because the initial values for the carbonate system vary with the salinity of each of the ponds, there is no single trend that describes the evolution of $\delta^{13} \mathrm{C}_{\mathrm{\Sigma CO}_{2}}$ with degree of $\mathrm{NO}_{3}{ }^{-}$depletion. Using the same type of isotope mass balance as before, the changes in $\delta^{13} \mathrm{C}_{\Sigma \mathrm{CO}_{2}}$ have been predicted for ponds with 3 different salinities (i.e. 3 different $\mathrm{NO}_{3}{ }^{-}$initial and $\sum \mathrm{CO}_{2 \text { initial }}$ ) and algal growth with a Redfield, ratio of 6.5 (Fig. 13C). The range of $\delta^{13} \mathrm{C}_{\mathrm{SCO}_{2}}$ values are fairly consistent with the trends predicted for algal growth with a low ( 6.5) $\mathrm{C}: \mathrm{N}$ ratio. A further trend, for a pond with a salinity of 20 and using a C:N ratio of 15 , shows that this ratio is probably the upper limit consistent with the measured
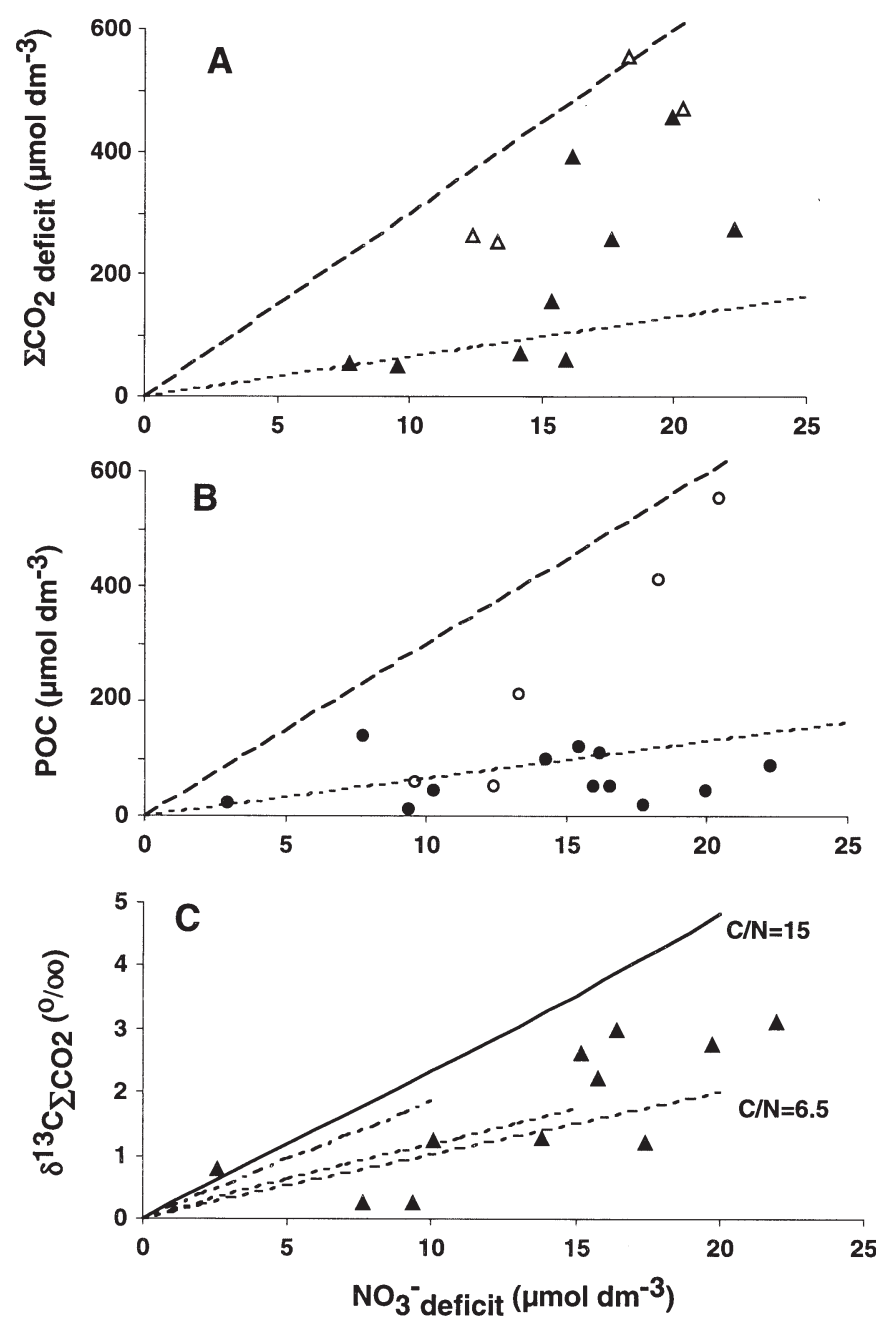

Fig. 13. Comparison of (A) $\sum \mathrm{CO}_{2}$ deficit and (B) particulate organic carbon (POC) with $\mathrm{NO}_{3}^{-}$deficit in surface ponds. Lines represent predicted trends using a $\left[\mathrm{NO}_{3}{ }^{-}\right.$initial $]$of $20 \mu \mathrm{mol} \mathrm{dm}{ }^{-3}$ and $\mathrm{C}: \mathrm{N}$ ratios of 6.5 (short dotted line) and 30 (long dotted line). (C) Comparison of $\delta^{13} \mathrm{C}_{\mathrm{\Sigma CO}_{2}}$ with $\mathrm{NO}_{3}^{-}$deficit in surface ponds. Lines represent predicted trends using $\left[\mathrm{NO}_{3}{ }^{-}{ }_{\text {initial }}\right]$ of 10,15 and $20 \mu \mathrm{mol} \mathrm{dm}{ }^{-3}$ and a C:N ratio of 6.5 (dotted line), and a $\left[\mathrm{NO}_{3}{ }^{-}\right.$initial $]$of $20 \mu \mathrm{mol} \mathrm{dm}{ }^{-3}$ and a $\mathrm{C}: \mathrm{N}$ ratio of 15 . Solid symbols represent data common to all 3 comparisons 
$\delta^{13} \mathrm{C}_{\Sigma \mathrm{CO}_{2}}$. However, the $\delta^{13} \mathrm{C}_{\mathrm{CCO}_{2}}$ was only measured in a sub-set of the ponds sampled and those with high $\mathrm{C}: \mathrm{N}$ ratios are not well represented (Fig. 13C). Thus, the data from the ponds represent different end points that result from individual batch-culture type of development in each of the ponds.

\section{CONCLUSIONS}

The data show that ice algae can accumulate far in excess of maximum standing stocks predicted in a closed system, by complete utilisation of major nutrients present in the open water. The highest biomass is found at the interface between ice and water, where water exchange allows replenishment of nutrients while the ice provides a physical support for the algae to be retained within its matrix. The data that conform to predictions of algal growth in a closed system have been collected from the interior of ice floes where there is essentially no potential for nutrient exchange. Thus, nutrient supply exerts a significant control on algal growth and the sea ice habitat provides a continuum of conditions where nutrient supply and algal demand can vary. Temporal trends could not be explicitly addressed in this synoptic study, but the isotopic data reflect the different rates of algal supply to demand and imply a commonality in the process(es) leading to the highly variable [POC]. It is clear that the biogeochemistry of sea ice ecosystems is complex. The very dynamic changes that occur even within similar types of environment make consistent interpretations of spatially variable data difficult. Future research should be directed to time series studies that would help clarify some of the issues discussed here as well as providing a clearer picture of the control exerted by nutrient exchange on algal growth and physiology.

Acknowledgements. We would like to thank the captain and crew of RV 'Polarstern', the pilots and crew of the 'Wasserthal' helicopter service and J. Bareiss for vital help in the field. We thank P. Kennedy, G. Middleton, J. Anderson (Bangor), and M. Stürcken-Rodewald (Bremerhaven) for their help in the analytical work. The work was partially funded by the UK Natural Environment Research Council (Grants GT9/2894, GR9/3309), NERC JREI (GR3/EOO68), The British Council/ DAAD (ARC Programme), The Nuffield Foundation (UK), The Ministerio de Education y Culture (Spain) and the Hanse Institute of Advanced Study (Germany). The paper benefited from the comments of 2 anonymous reviewers.

\section{LITERATURE CITED}

Ackley SF, Sullivan CW (1994) Physical controls on the development and characteristics of Antarctic sea ice biological communities - a review and synthesis. Deep-Sea Res 41: 1583-1604
Bentaleb I, Fontugne M (1998) The role of the southern Indian Ocean in the glacial to interglacial atmospheric $\mathrm{CO}_{2}$ change: organic carbon isotope evidence. Global Planet Change 16-17:25-36

Burkhardt S, Riebesell U, Zondervan I (1999) Effects of growth rate, $\mathrm{CO}_{2}$ concentration, and cell size on the stable carbon isotope fractionation in marine phytoplankton. Geochim Cosmochim Acta 22:3729-3741

Dehairs F, Kopczynska E, Nielsen P, Lancelot C, Bakker DCE, Koeve W, Goyens L (1997) $\delta^{13} \mathrm{C}$ of Southern Ocean suspended organic matter during spring and early summer: regional and temporal variability. Deep-Sea Res 44: 129-142

Dunbar RB, Leventer A (1992) Seasonal variation in carbon isotopic composition of Antarctic sea ice and open-water plankton communities. Antarct J US 7:79-81

Fischer G (1991) Stable carbon isotope ratios of plankton carbon and sinking organic matter from the Atlantic sector of the Southern Ocean. Mar Chem 35:581-596

Francois R, Altabet MA, Goericke R (1993) Changes in the $\delta^{13} \mathrm{C}$ of surface water particulate organic matter across the subtropical convergence in the SW Indian Ocean. Global Biogeochem Cycles 7:627-644

Fritsen CH, Lytle VI, Ackley SF, Sullivan CW (1994) Autumn bloom of Antarctic pack-ice algae. Science 266:782-784

Geider RJ, MacIntyre HL, Kana TM (1997) Dynamic model of phytoplankton growth and acclimation: response of the balanced growth rate and the chlorophyll a:carbon ratio to light, nutrient-limitation and temperature. Mar Ecol Prog Ser 148:187-200

Gibson JAE, Trull TW (1999) Annual cycle of $\mathrm{fCO}_{2}$ under seaice and in open water in Prydz Bay, East Antarctica. Mar Chem 66:187-200

Gibson JAE, Trull T, Nichols PD, Summons RE, McMinn A (1999) Sedimentation of ${ }^{13} \mathrm{C}$-rich organic matter from Antarctic sea-ice algae: a potential indicator of past sea ice extent. Geology 27:331-334

Gleitz M, Rutgers vd Loeff M, Thomas DN, Dieckmann GS, Millero FJ (1995) Comparison of summer and winter inorganic carbon, oxygen and nutrient concentrations in Antarctic sea ice brine. Mar Chem 51:81-91

Gleitz M, Kukert H, Riebesell U, Dieckmann GS (1996a) Carbon acquisition and growth of Antarctic sea ice diatoms in closed bottle incubations. Mar Ecol Prog Ser 135:169-177

Gleitz M, Grossmann S, Scharek R, Smetacek V (1996b) Ecology of diatom and bacterial assemblages in water associated with melting summer sea ice in the Weddell Sea, Antarctica. Antarct Sci 8:135-146

Gruber N, Keeling CD, Bacastow RB, Guenther PR and 5 others (1999) Spatiotemporal patterns of carbon-13 in the global surface oceans and the oceanic Suess effect. Global Biogeochem Cycles 13:307-335

Günther S, Dieckmann GS (1999) Seasonal development of algal biomass in snow-covered fast ice and the underlying platelet layer in the Weddell Sea, Antarctica. Antarct Sci 11:305-315

Günther S, Gleitz M, Dieckmann GS (1999) Biogeochemistry of Antarctic sea ice: a case study on platelet ice layers at Drescher Inlet, Weddell Sea. Mar Ecol Prog Ser 177:1-13

Haas C, Thomas DN, Steffens M, Bareiss J (1998) Physical and biological investigations of sea ice. In: Jokat W, Oerter $\mathrm{H}$ (eds) The expedition Antarktis-XIV of RV 'Polarstern' in 1997. Report of leg ANT-XIV/3. Ber Polarforsch 267:18-30

Haas C, Thomas DN, Bareiss J (2001) Surface properties and processes of perennial Antarctic sea ice in summer. J Glaciol 47:613-625 
Kattner G (1999) Storage of dissolved inorganic nutrients in seawater: poisoning with mercuric chloride. Mar Chem 67:61-66

Kattner G, Becker H (1991) Nutrients and organic nitrogenous compounds in the marginal ice zone of Fram Strait. J Mar Syst 2:385-394

Kennedy H, Robertson J (1995) Variations in the isotopic composition of particulate organic carbon in surface waters along an $88^{\circ} \mathrm{W}$ transect from $67^{\circ} \mathrm{S}$ to $54^{\circ} \mathrm{S}$. Deep-Sea Res 42:1109-1122

Lake RA, Lewis EL (1970) Salt rejection by sea ice during growth. J Geophys Res 75:583-597

Laws EA, Popp BN, Bidigare RR, Kennicutt MC, Macko SA (1995) Dependence of phytoplankton carbon isotopic composition on growth rate and $\left[\mathrm{CO}_{2}(\mathrm{aq})\right]$ : theoretical considerations and experimental results. Geochim Cosmochim Acta 59:1131-1138

Laws EA, Popp BN, Bidigare RR (1997) Effect of growth rate and $\mathrm{CO}_{2}$ concentration on carbon isotope fractionation by the marine diatom Phaeodactylum tricornutum. Limnol Oceanogr 42:1552-1560

McCorkle DC (1987) Stable carbon isotopes in deep sea pore waters: modern geochemistry and palaeoceanographic applications. PhD thesis, University of Washington, WA

McMinn A, Skerratt J, Trull T, Ashworth C, Lizotte M (1999) Nutrient stress gradient in the bottom $5 \mathrm{~cm}$ of fast ice, McMurdo Sound, Antarctica. Polar Biol 21:220-227

Mehrbach C, Culberson CH, Hawley JE, Pytkowicz RM (1973) Measurement of the apparent dissociation constant of carbonic acid in seawater at atmospheric pressure. Limnol Oceanogr 18:897-907

Nichol S, Allison I (1997) The frozen skin of the Southern Ocean. Am Sci 85:426-439

Palmisano AC, Garrison DL (1993) Microorganisms in Antarctic sea ice. In: Friedman EI (ed) Antarctic microbiology. Wiley-Liss, New York, p 167-218

Popp BN, Trull T, Kenig F, Wakeham SG and 7 others (1999) Controls on the carbon isotopic composition of Southern Ocean phytoplankton. Global Biogeochem Cycles 13: 827-843

Priscu JC, Sullivan CW (1998) Nitrogen metabolism in Antarctic fast-ice microalgal assemblages. In: Lizotte MP,

Editorial responsibility: Otto Kinne (Editor),

Oldendorf/Luhe, Germany
Arrigo KR (eds) Antarctic sea ice biological processes. Antarctic Res Ser 73, American Geophysical Union, Washington, DC, p 147-160

Rau GH, Takahashi T, DesMarias DJ (1989) Latitudinal variations in plankton $\delta^{13} \mathrm{C}$ : implications for $\mathrm{CO}_{2}$ and productivity in past oceans. Nature 341:516-518

Rau GH, Takahashi T, DesMarias DJ, Sullivan CW (1991a) Particulate organic matter $\delta^{13} \mathrm{C}$ variations across the Drake passage. J Geophys Res 96:15131-15135

Rau GH, Sullivan CW, Gordon LI $(1991 b) \delta^{13} \mathrm{C}$ and $\delta^{15} \mathrm{~N}$ variations in Weddell Sea particulate organic matter. Mar Chem 35:355-369

Rau GH, Takahashi T, DesMarias DJ, Repeta DJ, Martin JH (1992) The relationship between $\delta^{13} \mathrm{C}$ of organic matter and $\left[\mathrm{CO}_{2(\mathrm{aq})}\right]$ in ocean surface water: data from a JGOFS site in the northeast Atlantic Ocean and a model. Geochim Cosmochim Acta 56:1413-1419

Rau GH, Riebesell U, Wolf-Gladrow D (1997) $\mathrm{CO}_{2 \mathrm{aq}}$-dependent photosynthetic ${ }^{13} \mathrm{C}$ fractionation in the ocean: a model versus measurements. Global Biogeochem Cycles 11:267-278

Schnack-Schiel SB, Thomas DN, Haas C, Dieckmann GS, Alheit R (2001) The occurrence of the copepods Stephos longipes (calanoida) and Drescheriella glacialis (Harpacticoida) in summer sea ice in the Weddell Sea (Antarctica). Antarct Sci 13:150-157

Smith REH, Harrison WG, Harris LR, Herman AW (1990) Vertical fine structure of particulate matter and nutrients in sea ice of the high Arctic. Can J Fish Aquat Sci 47 1348-1355

Thomas DN, Lara RJ, Haas C, Schnack-Schiel SB, Dieckmann GS, Kattner G, Nöthig EM, Mizdalski E (1998) Biological soup within decaying summer sea ice in the Amundsen Sea, Antarctica. In: Lizotte MP, Arrigo KR (eds) Antarctic sea ice biological processes. Antarctic Res Ser 73, American Geophysical Union, Washington, DC p 161-171

Thomas DN, Kennedy H, Kattner G, Gerdes D, Gough C, Dieckmann GS (2001) Biogeochemistry of platelet ice: influence on particle flux under land fast sea ice during summer at Drescher Inlet, Weddell Sea, Antarctica. Polar Biol 24:486-496

Submitted: June 18, 2001; Accepted: April 30, 2002

Proofs received from author(s): July 19, 2002 